\title{
Pertumbuhan Varietas Jagung (Zea Mays L) Dengan Pengaturan Jarak Tanam
}

\author{
Laila Nazirah $^{1}$, Maisura ${ }^{2}$, Deri Triansyah ${ }^{3}$, Halus Satriawan ${ }^{4}$ \\ ${ }^{12}$ Dosen Program Studi Agroekoteknologi Fakultas Pertanian Universitas Malikussaleh \\ ${ }^{3}$ Alumni Program Studi Agroekoteknologi Fakultas Pertanian Universitas Malikussaleh \\ ${ }^{4}$ Dosen Program Studi Agroteknologi Fakultas Pertanian Universitas Almuslim \\ Email: laila_nazirah@yahoo.co.id, satriawan_80@yahoo.co.id
}

Diterima 12 Juni 2021/Disetujui 26 Juni 2021

\begin{abstract}
ABSTRAK
Tanaman Jagung (Zea mays L) merupakan komoditas pangan nomor 3 terpenting setelah padi dan kedelai, serta telah dimanfaatkan sebagai sumber karbohidrat, minyak dan tepung. Budidaya untuk beberapa varietas jagung di Aceh Utara belum memiliki acuan atau rekomendasi jarak tanam yang tepat sehingga hasil yang dicapai belum maksimal. Untuk itu perlu dikaji kombinasi antara varietas dan jarak tanam untuk mendapatkan jarak tanam sesuai dengan varietas yang ditanam. Penelitian ini dilaksanakan di Desa Tambon Tunong Kecamatan Dewantara Kabupaten Aceh Utara dengan ketinggian tempat 10 meter di atas permukaan laut (mdpl) dari bulan November 2020 s.d Januari 2021. Penelitian menggunakan Rancangan Acak Kelompok (RAK) faktorial dengan 12 kombinasi perlakuan dan 3 ulangan sehingga diperoleh 36 unit percobaan. Faktor pertama adalah Varietas (V) terdiri dari 4 taraf, yaitu V1 (Varietas Lamuru), V2 (Varietas Bisma), V3 (Varietas Srikandi Kuning-1), dan V4 (Varietas Anoman-1). Faktor kedua adalah jarak tanam (J) yang terdiri dari 3 taraf, yaitu $\mathrm{J} 1(60 \mathrm{~cm}$ x $20 \mathrm{~cm}), \mathrm{J} 2(70 \mathrm{~cm}$ x $50 \mathrm{~cm})$, dan J3 $(80 \mathrm{~cm}$ x $20 \mathrm{~cm})$. Berdasarkan hasil penelitian menunjukkan perlakuan varietas berpengaruh nyata terhadap tinggi tanaman umur (2 dan 4 MST) serta jumlah daun (2 MST). Perlakuan varietas juga berpengaruh sangat nyata terhadap tinggi tanaman (8 MST), umur berbunga, namun perlakuan varietas tidak berpengaruh nyata terhadap tinggi tanaman (6 MST), jumlah daun (4, 6 dan 8 MST), diameter batang (2, 4, 6 dan 8 MST). Sedangkan pada perlakuan jarak tanam berpengaruh nyata terhadap umur berbunga, namun perlakuan jarak tanam tidak berpengaruh nyata terhadap tinggi tanaman (2, 4, 6 dan 8 MST), jumlah daun (2, 4, 6 dan 8 MST), diameter batang (2, 4, 6, dan 8 MST). Terdapat interaksi antara kombinasi perlakuan varietas dan jarak tanam terhadap jumlah daun 2 MST, kombinasi perlakuan terbaik terdapat pada perlakuan varietas Bisma dan jarak tanam 60x20 cm.
\end{abstract}

Kata kunci: jagung, jarak tanam, pertumbuhan, varietas

\section{PENDAHULUAN}

Tanaman Jagung (Zea mays L) merupakan komoditas pangan nomor 3 terpenting setelah padi dan kedelai. Jagung mempunyai kandungan gizi dan serat kasar yang cukup sebagai bahan makanan pokok pengganti beras. Selain sebagai sumber karbohidrat, jagung juga ditanam sebagai pakan ternak (hijauan maupun tongkolnya), diambil minyaknya (dari biji), dibuat tepung (dari biji, disebut tepung jagung atau maizena), dan bahan baku industri (dari tepung biji dan tongkolnya) (Yasin, et al., 2018).

Badan Pusat Statistik (2019), melaporkan bahwa produksi jagung di Provinsi Aceh tahun 2018 sebanyak 348 ton, mengalami penurunan sebesar 39 ton dari tahun 2017 yaitu sebanyak 387 ton. Hasil produksi jagung tahun 2017 merupakan angka produksi tertinggi dibandingkan tahun sebelumnya. Upaya peningkatan produksi jagung masih menghadapi berbagai masalah, sehingga jagung dalam negeri belum mampu mencukupi kebutuhan nasional. Upaya yang dapat dilakukan guna meningkatkan produksi tanaman jagung di Indonesia salah satunya dengan menanam benih varietas unggul dan jarak tanam yang sesuai. Varietas Lamuru memiliki ketahanan terhadap penyakit bulai dan karat daun dengan rata-rata hasil 5,6 ton/ha. Varietas Bisma memiliki keunggulan tahan terhadap penyakit karat dan bercak daun dengan rata-rata hasil 5,7 ton/ha pipilan kering, sedangkan jagung varietas Srikandi Kuning memiliki ketahanan terhadap penyakit hawar dan karat daun serta hama penggerek batang dengan rata-rata hasil 5,4 ton/ha (Balai Penelitian Tanaman Serealia, 2016). Yasin, 
et al. (2014), menyatakan bahwa jagung varietas Anoman-1 memiliki keunggulan toleran terhadap cekaman kekeringan serta kandungan karbohidrat dan gizi yang menyamai beras dan gandum.

Penggunaan benih varietas unggul perlu diikuti dengan upaya yang lain, yaitu dengan pengaturan jarak tanam yang tepat agar memperoleh hasil yang optimal. Yulisma (2011), menambahkan bahwa populasi merupakan faktor yang dapat mempengaruhi hasil tanaman. Peningkatan hasil jagung dapat diupayakan melalui pengaturan kerapatan tanam hingga mencapai populasi optimal. Ikhwani, et al. (2013) menambahkan bahwa penerapan jarak tanam yang efektif bertujuan untuk memberikan kemungkinan tanaman agar tumbuh dengan baik tanpa mengalami banyak persaingan dalam hal ketersediaan air, unsur hara dan cahaya matahari secara optimal untuk proses fotosintesis. Kartika (2018) menunjukkan bahwa jarak tanam 60x20 cm merupakan pengaturan jarak tanam yang baik bagi tanaman jagung, karena jarak tanam tersebut dapat mengurangi terjadinya persaingan untuk mendapatkan unsur hara. Aisyah., Herlina (2018) menambahkan bahwa penggunaan jarak tanam $80 \times 20 \mathrm{~cm}$ pada tanaman jagung memberikan hasil yang optimal karena pada jarak tanam tersebut menghasilkan populasi lebih banyak sehingga berpengaruh terhadap produksi tanaman. Oleh karena itu, perlu dilakukan penelitian untuk mengetahui pertumbuhan beberapa varietas tanaman jagung yang ditanam dengan jarak tanam berbeda serta interaksi keduanya.

\section{METODE PENELITIAN}

Penelitian ini menggunakan metode Rancangan Acak Kelompok Faktorial (RAKF), yaitu: 1) faktor pertama varietas jagung $(\mathrm{V})$, dengan 4 varietas jagung $(\mathrm{V} 1=$ Lamuru, V2= Bisma, V3= Srikandi Kuning-1, dan V4= Anoman-1); dan 2) faktor kedua jarak tanam jagung (J), dengan 3 jarak tanam jangung $(\mathrm{J} 1=60 \times 20 \mathrm{~cm}, \mathrm{~J} 2=70 \times 50 \mathrm{~cm}, \mathrm{~J} 3=80 \times 20 \mathrm{~cm})$. Penelitian ini dilakukan di Desa Tambon Tunong pada ketinggian $10 \mathrm{mdpl}$ dan di Laboraturium Fakultas Pertanian Universitas Malikussaleh pada bulan November 2020 s.d Januari 2021. Bahan-bahan yang digunakan adalah pupuk dasar yaitu pupuk organik kandang sapi, TSP, $\mathrm{KCl}$ dan Urea. Benih yang digunakan adalah 4 varietas yaitu varietas Lamuru, varietas Bisma, varietas Srikandi Kuning-1 dan varietas Anoman-1. Pestisida Permifos 550EC digunakan untuk mengendalikan hama pada tanaman. Sedangkan, alat-alat yang digunakan adalah cangkul, gembor, sekop, meteran, gembor, timbangan analitik, ember, karung, papan nama, kamera dan alat tulis. Pengamatan dilakukan pada komponen pertumbuhan sebanyak 4 kali, yaitu 2, 4, 6 dan 8 minggu setelah tanam (MST), dengan variabel pengamatan yang diamati berupa: 1) tinggi tanaman $(\mathrm{cm})$, diukur dari pangkal batang sampai ujung daun tertinggi, dengan membuat patok standar dekat pangkal batang dipermukaan tanah menggunakan meteran; dan 2) jumlah daun (helai), diamati dengan menghitung jumlah daun yang telah membuka sempurna, yang diinyatakan dalam satuan helai; 3 ) diameter batang $(\mathrm{cm})$, diukur pada pangkal batang menggunakan jangka sorong, dengan membuat patok standar $2 \mathrm{~cm}$ di atas permukaan tanah dimulai dari ujung patok; 4) umur berbunga (hari), yang ditetapkan jika 50\% tanaman dalam satuan percobaan telah mengeluarkan bunga jantan yang dinyatakan dalam satuan hari. Adapun semua data yang diperoleh dari hasil pengamatan dianalisis menggunakan sidik ragam (ANOVA), dengan Rancangan Acak Kelompok (RAK) dan dilanjutkan dengan uji Duncan 5\%.

\section{HASIL DAN PEMBAHASAN}

Hasil rekapitulasi analisis ragam pertumbuhan dan hasil beberapa varietas tanaman jagung (Zea Mays L) dan perlakuan jarak tanam serta interaksi keduanya terhadap tinggi tanaman, jumlah daun, diameter batang, umur berbunga, terlihat sebagai berikut: 
Tabel 1. Hasil Rekapitulasi Analisis Ragam Respon Pertumbuhan dan Hasil Akibat Penggunaan Beberapa Varietas Tanaman Jagung (Zea mays L) dan Jarak Tanam

\begin{tabular}{|c|c|c|c|c|}
\hline \multirow{2}{*}{ Peubah } & \multicolumn{4}{|c|}{ Perlakuan } \\
\hline & Varietas $(\mathrm{V})$ & Jarak Tanam $(\mathrm{J})$ & Interaksi $(\mathrm{V} * \mathrm{~J})$ & KK \% \\
\hline \multicolumn{5}{|l|}{ Tinggi Tanaman } \\
\hline $2 \mathrm{MST}$ & * & tn & tn & 7,41 \\
\hline $4 \mathrm{MST}$ & * & tn & tn & 10,57 \\
\hline $6 \mathrm{MST}$ & tn & tn & tn & 14,81 \\
\hline $8 \mathrm{MST}$ & $* *$ & tn & tn & 11,90 \\
\hline \multicolumn{5}{|l|}{ Jumlah Daun } \\
\hline $2 \mathrm{MST}$ & $*$ & tn & * & 10,87 \\
\hline $4 \mathrm{MST}$ & tn & tn & tn & 13,23 \\
\hline $6 \mathrm{MST}$ & tn & tn & tn & 11,18 \\
\hline $8 \mathrm{MST}$ & tn & tn & tn & 7,03 \\
\hline \multicolumn{5}{|l|}{ Diameter Batang } \\
\hline $2 \mathrm{MST}$ & tn & tn & tn & 16,97 \\
\hline $4 \mathrm{MST}$ & tn & tn & tn & 17,36 \\
\hline $6 \mathrm{MST}$ & tn & tn & tn & 15,36 \\
\hline $8 \mathrm{MST}$ & tn & tn & tn & 12,86 \\
\hline Umur Berbunga & $* *$ & $*$ & tn & 1,14 \\
\hline
\end{tabular}

Berdasarkan hasil rekapitulasi di atas diperoleh bahwa perlakuan varietas berpengaruh nyata terhadap tinggi tanaman umur 2 dan 4 MST serta jumlah daun 2 MST. Perlakuan varietas juga berpengaruh sangat nyata terhadap tinggi tanaman umur 8 MST, umur berbunga, bobot tongkol berkelobot, bobot tongkol tanpa kelobot, bobot pipilan kering dan produksi ton per hektar. Namun, perlakuan varietas tidak berpengaruh nyata terhadap tinggi tanaman umur 6 MST, jumlah daun umur 4, 6 dan 8 MST, diameter batang 2, 4, 6 dan 8 MST, jumlah baris biji per tongkol dan jumlah tongkol per tanaman. Sedangkan, perlakuan jarak tanam berpengaruh nyata terhadap umur berbunga, jumlah baris biji per tongkol, jumlah tongkol per tanaman dan bobot tongkol berkelobot, serta berpengaruh sangat nyata terhadap bobot tongkol tanpa kelobot dan bobot pipilan kering. Namun, perlakuan jarak tanam tidak berpengaruh nyata terhadap tinggi tanaman 2, 4, 6 dan 8 MST, jumlah daun 2, 4, 6 dan 8 MST, diameter batang 2, 4, 6, dan 8 MST, serta produksi ton per hektar. Selain itu, terdapat interaksi antara kombinasi perlakuan varietas dan jarak tanam terhadap jumlah daun 2 MST, bobot tongkol tanpa kelobot dan bobot pipilan kering.

\section{Tinggi Tanaman}

Hasil analisis ragam menunjukkan bahwa faktor interaksi varietas dan jarak tanam tidak berpengaruh terhadap peubah tinggi tanaman 2, 4, 6 dan 8 MST. Faktor tunggal perlakuan varietas berpengaruh pada peubah tinggi tanaman 2, 4, dan 8 MST. Sedangkan faktor jarak tanam tidak berpengaruh pada peubah tinggi tanaman. Hasil uji lanjut tinggi tanaman akibat perlakuan varietas dan jarak tanam secara tunggal menggunakan uji DMRT taraf 5\% terlihat sebagai berikut:

Tabel 2. Rata-Rata Tinggi Tanaman Jagung Akibat Penggunaan Beberapa Varietas dan Jarak Tanam yang Berbeda

\begin{tabular}{lcccc}
\hline \multirow{2}{*}{ Perlakuan } & \multicolumn{4}{c}{ Tinggi Tanaman $(\mathbf{c m})$} \\
\cline { 2 - 5 } & 2 MST & 4 MST & $6 \mathrm{MST}$ & $8 \mathrm{MST}$ \\
\hline Varietas & $51,70 \mathrm{~b}$ & $112,41 \mathrm{ab}$ & $141,84 \mathrm{a}$ & $170,70 \mathrm{ab}$ \\
\hline V1 (Varietas Lamuru) & $56,02 \mathrm{a}$ & $119,39 \mathrm{a}$ & $154,35 \mathrm{a}$ & $189,35 \mathrm{a}$ \\
V2 (Varietas Bisma) & $53,32 \mathrm{ab}$ & $116,18 \mathrm{a}$ & $147,30 \mathrm{a}$ & $178,19 \mathrm{a}$ \\
V3 (Varietas Srikandi Kuning -1) & $49,78 \mathrm{~b}$ & $103,24 \mathrm{~b}$ & $131,55 \mathrm{a}$ & $153,46 \mathrm{~b}$ \\
V4 (Varietas Anoman -1) & & & & \\
\hline Jarak Tanam & $52,56 \mathrm{a}$ & $113,20 \mathrm{a}$ & $144,55 \mathrm{a}$ & $174,45 \mathrm{a}$ \\
\hline J1 (60 cm x 20 cm) & $51,66 \mathrm{a}$ & $111,08 \mathrm{a}$ & $144,54 \mathrm{a}$ & $172,29 \mathrm{a}$
\end{tabular}


Berdasarkan data di atas, terlihat perlakuan varietas berpengaruh pada tinggi tanaman umur 2, 4 dan 8 MST yaitu pada varietas Bisma (V2) dengan nilai $(56,02 \mathrm{~cm}, 119,39 \mathrm{~cm}$ dan $189,35 \mathrm{~cm}$ ), dan nilai terendah pada varietas Anoman-1 (V4) dengan nilai (29,78 cm, 103,24 cm dan 153,46 cm). Lalu, tidak terdapat perbedaan yang sangat nyata pada perlakuan jarak tanam terhadap tinggi tanaman umur 2, 4, 6 dan 8 MST. Adapun nilai tertinggi tinggi tanaman umur 8 MST pada jarak tanam 60x20 cm (J1) dengan nilai $(174,45 \mathrm{~cm})$ dan nilai terendah pada jarak tanam 80x20 cm $(\mathrm{J} 3)$ dengan nilai $(172,04 \mathrm{~cm})$.

Varietas bisma memiliki nilai rataan tertinggi dibandingkan varietas lain, yaitu $189,35 \mathrm{~cm}$. Namun, belum sesuai dengan tinggi tanaman pada deskripsi varietas Bisma, yaitu sebesar $230 \mathrm{~cm}$. Perbedaan tinggi tanaman disebabkan faktor genetik setiap varietas berbeda serta faktor lingkungan yang mempengaruhi kemampuan setiap varietas untuk beradaptasi secara maksimal. Latuharhary., Saputro (2017), menyatakan bahwa varietas Bisma merupakan jagung golongan bersari bebas yang dilepas tahun 1995, mempunyai keunggulan potensi hasil mencapai 7,0 - 7,5 t/ha pipilan kering dengan umur panen 96 hari dan memiliki ketahanan terhadap penyakit karat dan bercak daun yang baik dibudidayakan pada dataran rendah dengan ketinggian di bawah 500 mdpl. Purba (2020), menyatakan bahwa jagung varietas Lamuru pada lahan marginal di daerah Singaraja, Bali menunjukkan nilai tinggi tanaman tertinggi $177,13 \mathrm{~cm}$ dan tidak berbeda nyata dengan varietas Bisma yaitu $169,00 \mathrm{~cm}$. Zulfitri (2005), menambahkan bahwa perbedaan tinggi tanaman pada setiap varietas mengindikasikan adanya perbedaan pertumbuhan, tanaman yang lebih tinggi memberikan hasil yang lebih baik dibanding tanaman yang lebih rendah, karena tanaman yang lebih tinggi dapat mempersiapkan organ vegetatif yang lebih baik sehingga organ fotosintat yang ada di daun akan dihasilkan lebih banyak.

Hasil penelitian menunjukkan bahwa perlakuan jarak tanam tidak memberikan pengaruh nyata terhadap tinggi tanaman. Namun, jarak tanam $60 \times 20 \mathrm{~cm}$ berpengaruh lebih baik dibanding perlakuan lainnya. Hal ini karena pengaturan tingkat kerapatan tanaman mengurangi kompetisi pengambilan unsur hara antartanaman. Aisyah., Herlina (2018), menyatakan tinggi tanaman dipengaruhi oleh tingkat kompetisi antartanaman, terutama kompetisi air, cahaya matahari dan ruang tumbuh semakin sempit, maka jarak tanam semakin tinggi tingkat kompetisi antartanaman. Yulisma (2011), menyebutkan tinggi tanaman akan mengalami pengurangan setiap penjarangan jarak dalam barisan.

\section{Jumlah Daun}

Hasil analisis ragam menunjukkan faktor interaksi varietas dan jarak tanam berpengaruh terhadap peubah jumlah daun 2 MST. Faktor tunggal perlakuan varietas berpengaruh pada peubah jumlah daun 2 MST. Sedangkan faktor jarak tanam tidak berpengaruh pada peubah jumlah daun. Hasil analisis ragam jumlah daun akibat perlakuan varietas dan jarak tanam dengan uji DMRT taraf 5\% yaitu:

Tabel 3. Interaksi Jumlah Daun Umur 2 MST Akibat Penggunaan Beberapa Varietas dan Jarak Tanam yang Berbeda

\begin{tabular}{lc}
\hline \multicolumn{1}{c}{ Perlakuan } & Jumlah Daun (helai) \\
\cline { 2 - 2 } V1J1 (Varietas Lamuru) $(60 \mathrm{~cm} \times 20 \mathrm{~cm})$ & $2 \mathrm{MST}$ \\
V1J2 (Varietas Lamuru) $(70 \mathrm{~cm} \times 50 \mathrm{~cm})$ & $4,00 \mathrm{a}$ \\
V1J3 (Varietas Lamuru) $(80 \mathrm{~cm} \times 20 \mathrm{~cm})$ & $4,00 \mathrm{a}$ \\
V2J1 (Varietas Bisma) $(60 \mathrm{~cm} \times 20 \mathrm{~cm})$ & $4,00 \mathrm{a}$ \\
V2J2 (Varietas Bisma) $(70 \mathrm{~cm} \times 50 \mathrm{~cm})$ & $3,33 \mathrm{ab}$ \\
V2J3 (Varietas Bisma) $(80 \mathrm{~cm} \times 20 \mathrm{~cm})$ & $3,66 \mathrm{ab}$ \\
V3J1 (Varietas Srikandi Kuning-1) $(60 \mathrm{~cm} \times 20 \mathrm{~cm})$ & $3,33 \mathrm{ab}$ \\
V3J2 (Varietas Srikandi Kuning -1$)(70 \mathrm{~cm} \times 50 \mathrm{~cm})$ & $3,00 \mathrm{~b}$ \\
V3J3 (Varietas Srikandi Kuning -1$)(80 \mathrm{~cm} \times 20 \mathrm{~cm})$ & $3,66 \mathrm{ab}$ \\
V4J1 (Varietas Anoman-1) $(60 \mathrm{~cm} \times 20 \mathrm{~cm})$ & $3,00 \mathrm{~b}$ \\
V4J2 (Varietas Anoman-1) $(70 \mathrm{~cm} \times 50 \mathrm{~cm})$ & $4,00 \mathrm{a}$
\end{tabular}


$4,00 \mathrm{a}$

Keterangan: Angka-angka yang diikuti huruf yang sama pada kolom yang sama tidak berbeda nyata menurut uji DMRT 5\%

Berdasarkan data di atas, terlihat bahwa kombinasi penggunaan varietas dan jarak tanam berpengaruh terhadap peubah jumlah daun umur 2 MST. Jumlah daun terbaik terdapat pada kombinasi perlakuan V1J1 (Varietas Lamuru, 60x20 cm), V1J2 (Varietas Lamuru, 70x50 cm), V1J3 (Varietas Lamuru, 80x20 cm), V2J1 (Varietas Bisma, 60x20 cm), V4J2 (Varietas Anoman-1, 70x50 cm), dan V4J3 (Varietas Anoman-1, 80x20 cm) sebesar (4,00 helai) dibanding kombinasi lainnya. Sedangkan, jumlah daun terendah terdapat pada kombinasi perlakuan V3J2 (Varietas Srikandi Kuning -1, 70x50 cm) dan V4J1 (Varietas Anoman-1, 60x20 cm) sebesar (3 helai). Hasil analisis ragam jumlah daun akibat perlakuan varietas dan jarak tanam secara tunggal menggunakan uji DMRT taraf 5\% sebagai berikut:

Tabel 4. Rata-rata Jumlah Daun Jagung Akibat Penggunaan Beberapa Varietas dan Jarak Tanam yang Berbeda

\begin{tabular}{|c|c|c|c|c|}
\hline \multirow{2}{*}{ Perlakuan } & \multicolumn{4}{|c|}{ Jumlah Daun (helai) } \\
\hline & $2 \mathrm{MST}$ & $4 \mathrm{MST}$ & $6 \mathrm{MST}$ & $8 \mathrm{MST}$ \\
\hline \multicolumn{5}{|l|}{ Varietas } \\
\hline V1 (Varietas Lamuru) & $4,00 \mathrm{a}$ & $7,00 \mathrm{a}$ & $8,44 \mathrm{a}$ & $12,44 \mathrm{a}$ \\
\hline V2 (Varietas Bisma) & $3,66 \mathrm{ab}$ & $7,55 \mathrm{a}$ & $9,22 \mathrm{a}$ & $13,11 \mathrm{a}$ \\
\hline V3 (Varietas Srikandi Kuning -1) & $3,33 \mathrm{~b}$ & $7,11 \mathrm{a}$ & $8,88 \mathrm{a}$ & $12,66 \mathrm{a}$ \\
\hline V4 (Varietas Anoman -1) & $3,66 \mathrm{ab}$ & $6,66 \mathrm{a}$ & $8,33 \mathrm{a}$ & $11,88 \mathrm{a}$ \\
\hline \multicolumn{5}{|l|}{ Jarak Tanam } \\
\hline $\mathrm{J} 1(60 \mathrm{~cm} \times 20 \mathrm{~cm})$ & $3,58 \mathrm{a}$ & $7,08 \mathrm{a}$ & 8,66 a & $12,41 \mathrm{a}$ \\
\hline $\mathrm{J} 2(70 \mathrm{~cm} \times 50 \mathrm{~cm})$ & $3,58 \mathrm{a}$ & $7,16 \mathrm{a}$ & $8,83 \mathrm{a}$ & $12,58 \mathrm{a}$ \\
\hline $\mathrm{J} 3(80 \mathrm{~cm} \times 20 \mathrm{~cm})$ & $3,58 \mathrm{a}$ & $7,00 \mathrm{a}$ & 8,66 a & $12,41 \mathrm{a}$ \\
\hline
\end{tabular}

Berdasarkan data di atas, terlihat bahwa perlakuan varietas berpengaruh pada jumlah daun umur 2 MST pada varietas Lamuru (V1) dengan nilai tertinggi (4 helai), dan nilai terendah pada varietas Srikandi Kuning-1 (V3) dengan nilai (3,33 helai). Selain itu, tidak terdapat perbedaan yang sangat nyata pada perlakuan jarak tanam terhadap jumlah daun umur 2, 4, 6 dan 8 MST. Terlihat nilai tertinggi jumlah daun umur 8 MST terdapat pada jarak tanam 70x50 cm (J2) dengan nilai (12,58 helai) dan nilai terendah pada jarak tanam 60x20 cm (J1) dan 80x20 cm (J3) dengan nilai (12,41 helai).

Daun berperan penting terhadap pertumbuhan dan perkembangan tanaman, semakin banyak jumlah daun, maka pertumbuhan tanaman semakin optimal. Daun berperan menyintesis bahan organik menggunakan sinar matahari sebagi sumber energi lewat proses fotosintesis. Menurut hasil penelitian yang telah dilakukan, penggunaan varietas Bisma menghasilkan jumlah daun terbanyak. Hal ini dikarenakan kemampuan yang berbeda dari setiap varietas dalam melakukan pembentukan daun sehingga fotosintesis tidak terjadi optimal, dengan banyaknya jumlah daun semakin banyak daun yang aktif dalam melakukan proses fotosintesis. Hasanah (2017), menyatakan bahwa jumlah daun berhubungan dengan proses fotosintesis, semakin banyak jumlah daun semakin banyak cahaya yang didapatkan tanaman, semakin tebal dan hijau daun semakin banyak fotosintat yang diterima tanaman.

Penggunaan beberapa jarak tanam tidak memberikan pengaruh terhadap jumlah daun, karena jarak tanaman yang rapat sebagian daun tanaman ternaungi oleh daun tanaman lain. Hal ini berpengaruh pada proses fotosintesis karena intensitas cahaya yang diterima tanaman tidak optimal sehingga menghambat pertumbuhan daun baru. Nuryadin, et al. (2016), menyatakan bahwa intesitas cahaya yang tidak optimal karena tanaman saling menaungi mengakibatkan daun tanaman menjadi lebih kecil, sehingga berpengaruh terhadap proses metabolisme menjadi kurang sempurna. Akibatnya daun tanaman yang ternaungi akan menjadi tipis dengan permukaan daun yang lebih luas. 


\section{Diameter Batang}

Hasil analisis ragam menunjukkan bahwa faktor interaksi varietas dan jarak tanam tidak berpengaruh terhadap peubah diameter batang 2, 4, 6 dan 8 MST. Faktor tunggal perlakuan varietas dan jarak tanam tidak berpengaruh pada peubah diameter batang. Hasil analisis ragam diameter batang akibat perlakuan varietas dan jarak tanam secara tunggal menggunakan uji DMRT taraf 5\% sebagai berikut:

Berdasarkan data pada tabel 5, terlihat bahwa perlakuan varietas tidak berpengaruh nyata pada diameter batang umur 2, 4, 6, dan 8 MST. Adapun nilai tertinggi diameter batang umur 8 MST terdapat pada varietas Bisma (V2) dengan nilai $(2,29 \mathrm{~cm})$ dan nilai terendah pada varietas Lamuru (V1) dengan nilai $(2,11 \mathrm{~cm})$. Namun, tidak terdapat perbedaan yang sangat nyata pada perlakuan jarak tanam terhadap diameter batang umur 2, 4, 6 dan 8 MST. Terlihat nilai tertinggi diameter batang umur 8 MST terdapat pada jarak tanam $70 \times 50 \mathrm{~cm}(\mathrm{~J} 2)$ dengan nilai $(2,33 \mathrm{~cm})$ dan nilai terendah terdapat pada jarak tanam 80x20 $\mathrm{cm}(\mathrm{J} 3)$ dengan nilai $(2,10 \mathrm{~cm})$.

Tabel 5. Rata-rata Diameter Batang Jagung Akibat Penggunaan Beberapa Varietas dan Jarak Tanam yang Berbeda

\begin{tabular}{|c|c|c|c|c|}
\hline \multirow{2}{*}{ Perlakuan } & \multicolumn{4}{|c|}{ Diameter Batang (cm) } \\
\hline & $2 \mathrm{MST}$ & $4 \mathrm{MST}$ & $6 \mathrm{MST}$ & $8 \mathrm{MST}$ \\
\hline \multicolumn{5}{|l|}{ Varietas } \\
\hline V1 (Varietas Lamuru) & $1,26 \mathrm{a}$ & $1,63 \mathrm{a}$ & $1,85 \mathrm{a}$ & $2,11 \mathrm{a}$ \\
\hline V2 (Varietas Bisma) & $1,28 \mathrm{a}$ & $1,76 \mathrm{a}$ & $1,97 \mathrm{a}$ & $2,29 \mathrm{a}$ \\
\hline V3 (Varietas Srikandi Kuning -1) & $1,18 \mathrm{a}$ & $1,69 \mathrm{a}$ & $1,90 \mathrm{a}$ & $2,24 \mathrm{a}$ \\
\hline V4 (Varietas Anoman -1) & $1,31 \mathrm{a}$ & $1,63 \mathrm{a}$ & $1,83 \mathrm{a}$ & $2,22 \mathrm{a}$ \\
\hline \multicolumn{5}{|l|}{ Jarak Tanam } \\
\hline $\mathrm{J} 1(60 \mathrm{~cm} \times 20 \mathrm{~cm})$ & $1,22 \mathrm{a}$ & $1,67 \mathrm{a}$ & $1,89 \mathrm{a}$ & $2,22 \mathrm{a}$ \\
\hline $\mathrm{J} 2(70 \mathrm{~cm} \times 50 \mathrm{~cm})$ & $1,34 \mathrm{a}$ & $1,79 \mathrm{a}$ & $2,00 \mathrm{a}$ & $2,33 \mathrm{a}$ \\
\hline $\mathrm{J} 3(80 \mathrm{~cm} \times 20 \mathrm{~cm})$ & $1,21 \mathrm{a}$ & $1,56 \mathrm{a}$ & $1,77 \mathrm{a}$ & $2,10 \mathrm{a}$ \\
\hline
\end{tabular}

Keterangan: Angka-angka yang diikuti huruf yang sama pada kolom yang sama tidak berbeda nyata menurut uji DMRT 5\%

Batang berperan penting dalam pertumbuhan dan perkembangan tanaman, karena batang merupakan jalur transportasi air dan zat hara. Hasil penelitian menunjukkan bahwa penggunaan beberapa varietas dan jarak tanam tidak memberikan pengaruh pada peubah diameter batang, dikarenakan kurangnya unsur hara nitrogen dan fosfat yang diberikan ke tanaman jagung. Damanik, et al. (2011), menyatakan bahwa nitrogen dalam tanaman sangat penting untuk menentukan pembentukan protein dan senyawa organik lainnya, nitrogen adalah unsur hara yang paling banyak dibutuhkan tanaman. Yandianto (2003), menambahkan bahwa unsur hara fosfat berguna bagi tanaman terutama untuk pertumbuhan dan perkembangan, misalnya pertumbuhan anakan tanaman, cabang, tunas dan batang tanaman. Berdasarkan hasil penelitian, batang tanaman bertambah besar sejak awal pertumbuhan hingga waktu pengukuran terakhir. Penggunaan beberapa jarak tanam tidak memberikan pengaruh nyata terhadap peubah diameter batang. Namun, jarak tanam yang renggang, yaitu $70 \times 50 \mathrm{~cm}$ lebih efektif dalam pertumbuhan batang.

\section{Umur Berbunga}

Hasil analisis ragam menunjukkan bahwa faktor interaksi varietas dan jarak tanam tidak berpengaruh terhadap peubah umur berbunga. Faktor tunggal perlakuan varietas berpengaruh sangat nyata pada peubah umur berbunga dan perlakuan jarak tanam berpengaruh nyata pada peubah umur berbunga. Hasil analisis ragam umur berbunga akibat perlakuan varietas dan jarak tanam secara tunggal menggunakan uji DMRT taraf 5\% sebagai berikut:

Tabel 6. Rata-rata Umur Berbunga Jagung Akibat Penggunaan Beberapa Varietas dan Jarak Tanam yang Berbeda

\begin{tabular}{lc}
\hline \multicolumn{1}{c}{ Perlakuan } & Umur Berbunga (hari) \\
\hline Varietas & \\
\hline V1 (Varietas Lamuru) & $56,66 \mathrm{c}$ \\
V2 (Varietas Bisma) & $61,33 \mathrm{a}$
\end{tabular}




\begin{tabular}{ll} 
V3 (Varietas Srikandi Kuning -1) & $57,44 \mathrm{~b}$ \\
V4 (Varietas Anoman -1) & $57,22 \mathrm{bc}$ \\
\hline Jarak Tanam & \\
\hline J1 $(60 \mathrm{~cm} \times 20 \mathrm{~cm})$ & $57,75 \mathrm{~b}$ \\
$\mathrm{~J} 2(70 \mathrm{~cm} \times 50 \mathrm{~cm})$ & $58,58 \mathrm{a}$ \\
$\mathrm{J} 3(80 \mathrm{~cm} \times 20 \mathrm{~cm})$ & $58,16 \mathrm{ab}$ \\
\hline
\end{tabular}

Keterangan: Angka-angka yang diikuti huruf yang sama pada kolom yang sama tidak berbeda nyata menurut uji DMRT 5\%

Berdasarkan data di atas, terlihat perlakuan varietas berpengaruh sangat nyata pada umur berbunga. Adapun nilai umur berbunga tercepat terdapat pada varietas Lamuru (V1) dengan nilai (56,66 hari) dan nilai terendah pada varietas Bisma (V2) dengan nilai (61,33 hari). Perlakuan jarak tanam berpengaruh nyata pada umur berbunga, nilai umur berbunga tercepat pada jarak tanam $60 \times 20 \mathrm{~cm}(\mathrm{~J} 1)$ dengan nilai (57,75 hari) dan nilai terendah pada jarak tanam 70x50 cm (J2) dengan nilai (58,58 hari).

Setiap varietas memiliki lama pertumbuhan generatif yang berbeda, sehingga waktu berbunga setiap varietas juga berbeda. Penggunaan varietas Lamuru menginduksi bunga lebih cepat dibandingkan varietas lain. Hal ini disebabkan oleh faktor genetik dan faktor lingkungan, yaitu penanaman dilakukan saat musim hujan. Berdasarkan hasil penelitian, umur munculnya bunga jantan pada tanaman jagung dipengaruhi oleh jarak tanam. Hasil analisis ragam menunjukkan perlakuan jarak tanam memperlihatkan perbedaan yang nyata terhadap umur berbunga, yaitu pada penggunaan jarak tanam $60 \times 20 \mathrm{~cm}$ memunculkan bunga lebih cepat dibanding jarak tanam lain. Hasil ini menunjukkan penggunaan jarak tanam yang lebih rapat mengakibatkan umur berbunga semakin cepat. Kartika (2018), menyatakan bahwa semakin rapat jarak tanam mengakibatkan umur berbunga tanaman jagung semakin lambat, sebaliknya semakin jarang jarak tanam semakin cepat waktu keluar bunga.

\section{SIMPULAN}

Berdasarkan hasil dan pembahasan penelitian, disimpulkan bahwa: 1) perlakuan penggunaan varietas berpengaruh terhadap pertumbuhan dan hasil tanaman jagung pada peubah tinggi tanaman ( 2 dan 4 MST), jumlah daun (2 MST), umur berbunga, dengan perlakuan terbaik terdapat pada penggunaan varietas Bisma; 2) perlakuan penggunaan jarak tanam berpengaruh terhadap pertumbuhan dan hasil tanaman jagung pada peubah umur berbunga, dengan perlakuan terbaik terdapat pada penggunaan jarak tanam $60 \times 20 \mathrm{~cm}$; 3) terdapat interaksi antara kombinasi perlakuan penggunaan beberapa varietas dan jarak tanam terhadap pertumbuhan tanaman jagung pada peubah jumlah daun (2 MST), dengan interaksi perlakuan terbaik pada perlakuaan varietas Bisma dengan jarak tanam 60x20 cm.

\section{REFERENSI}

Aisyah, Y., Herlina, N. 2018. Pengaruh Jarak Tanam Jagung Manis (Zea $\quad$ mays $\quad$ L. $\quad$ Var saccharata) pada Tumpangsari dengan Tiga Varietas Tanaman Kedelai (Glycine max (L.). Jurnal Produksi Tanaman, 6 (1).

Badan Pusat Statistik. 2019. Produksi Jagung di Indonesia. diakses pada tanggal 1 Desember 2020.

Damanik, M.M.B., dkk. 2011. Kesuburan Tanah dan Pemupukan. Medan: USU Press.

Hasanah, I. 2017. Pengaruh Dosis Pupuk NPK dan Formulasi Pupuk Hayatiterhadap Produksi dan Mutu Benih Jagung Hibrida di Lapang. Bogor: Skripsi Fakultas Pertanian IPB.

Ikhwani, Pratiwi, G.R., Paturrohman, E., Makarim, A.K. 2013. Peningkatan $\quad$ Produktivitas Padi Melalui Penerapan Jarak Tanam Jajar Legowo. Jurnal IPTEK Tanaman Pangan, 8 (2).

Kartika, T. 2018. Pengaruh Jarak Tanam terhadap Pertumbuhan dan Produksi Jagung(Zea Mays L) Non Hibrida di Lahan Balai Agro Teknologi Terpadu (ATP). Jurnal Ilmiah Matematika dan Ilmu Pengetahuan Alam,15 (2). 
Latuharhary, R.A., Saputro, T.B. 2017. Respon Morfologi Tanaman Jagung (Zea mays) Varietas Bisma dan Srikandi Kuning pada Kondisi Cekaman Salinitas Tinggi. Jurnal Sains dan Seni ITS, 6 (2).

Nuryadin, A.K., Suprapti., Budiyono, A. 2016. Pengaruh Jarak Tanam dan Dosis Pupuk NPK pada Pertumbuhan dan Hasil Jagung Manis (Zea mays saccharate, Sturt). Jurnal Agrineca, 16 (2).

Purba, J.H. 2020. Adaptasi Varietas dan Galur Jagung pada Lahan Marginal. Jurnal Agrihitap, 5 (1).

Yandianto. 2003. Bercocok Tanam Padi. Bandung: M2S.

Yasin, M.H.G., Longgo, W., Faesal. 2014. Jagung Berbiji Putih sebagai Bahan Pangan Pokok Alternatif. Jurnal IPTEK Tanaman Pangan, 9 (2).

Yasin, M.H.G., dkk. 2018. Perkembangan Perakitan Varietas dan Teknik Budidaya Jagung Antioksi dan sebagai Pangan Fungsional. Jurnal Litbang Pertanian, 37.

Yulisma. 2011. Pertumbuhan dan Hasil Beberapa Varietas Jagung pada Berbagai Jarak Tanam. Jurnal Penelitian Pertanian Tanaman Pangan, 30 (3).

Zulfitri. 2005. Analisi Varietas Terhadap Pertumbuhan serta Hasil Cabai (Capssicum annum L.) Sistem Hidroponik. Buletin Penelitian, (8). 